\title{
The Prevention of Children as Victims of Human Trafficking
}

DOI: https://doi.org/10.47175/rissj.v2i3.248

\section{| Nursariani Simatupang |}

Faculty of Law, Universitas Muhamadiyah Sumatera Utara, Medan, Indonesia nursarianisimatupang@umsu. ac.id

\begin{abstract}
Trafficking in persons is a crime that often occurs. Children are very vulnerable to become victims of human trafficking. Child trafficking is an act that is very inhumane and destroys the future of children. Child trafficking is usually carried out by persuasion, making promises, and deceiving the victims. Therefore, precautions must be taken to minimize child trafficking. To prevent this, several efforts were made, including improving the family economy, creating a harmonious family, increasing religious understanding, negative impacts and legal consequences of child trafficking, increasing supervision on children, keeping children away from hedonistic lifestyles and consumptive behavior, getting to know children's social environment, increasing children's education and skills.

KEYWORDS

prevention; children; victims; trafficking in persons
\end{abstract}

\section{INTRODUCTION}

Each citizen has the proper to feel secure and free from all forms of separation. This is often in understanding with the logic of Pancasila and the 1945 Structure of the Republic of Indonesia. Specifically for the protection of children it is contained in Article 28B section 2 which states: "Each child has the proper to outlive, develop and create and has the proper to security from viciousness and segregation.

Law 35 of 2014 concerning Revisions to Law Number 23 of 2002 concerning Child Security in Article 59 states that the Government, Territorial Government, and other state teach are obliged and mindful for giving Uncommon Security to Children. One of the special protections for children as intended is given to children as victims of trafficking in persons.

Specifically in Indonesia regarding trafficking in people is controlled in Law Number 21 of 2007 concerning Annihilation of the Wrongdoing of Trafficking in People. Regarding child trafficking, Article 76F of Law Number 35 of 2014 stipulates that everyone is prohibited from placing, allowing, carrying out, ordering to do, or participating in kidnapping, selling, and/or trafficking children.

The crime of trafficking in persons often makes children as victims. Child trafficking is a reality that often happens and keeps on repeating itself. Child trafficking is an act that is very damaging to dignity and dignity. As a crime, the crime of trafficking in persons is also a form of human rights violation (Mahrus Ali and Bayu Aji Pramono, 2011).

Child trafficking continues to occur every day. However, not a few members of the community seem to turn a blind eye to the crime, and do not take preventive measures. There are still members of the community, especially parents who still leave their children unsupervised in their daily lives. Children are still used to doing activities without the assistance and supervision of their parents. In fact, this can open up the possibility of children falling into child trafficking. 
Trafficking in children has a very bad impact on the growth and development of children. Even child trafficking can ruin his future life. Some of the children who are victims of trafficking are even used as child sex workers. Of course this is very fatal for children and can cause great trauma.

Children are weak and helpless creatures who need love and attention (MG. Endang Sumiarni and Chandera Halim, 2000).

Children are the following era of the country and the successor of improvement, specifically the era that's arranged as the subject of actualizing economical development and controlling the longer term of a nation (Nashriana, 2012). For this reason, efforts need to be made from an early age to prevent children from crime, especially the crime of trafficking in persons.

Starting from the description of the background above, there are several things that become legal issues in this research, including the following:

a. What is the mode of child trafficking?

b. How to prevent children as casualties of trafficking in persons?

\section{RESEARCH METHODS}

This inquire about may be a standardizing juridical inquire about, namely research with an approach that is carried out based on legal materials, by examining library materials, in the form of legal principles, concepts, and related laws and regulations.

The source of data in this study is auxiliary information, which comprises of essential legitimate materials, auxiliary lawful materials, and tertiary lawful materials. The data collection tool used is a documentation study.

\section{RESULTS AND DISCUSSION}

Trafficking or trafficking is used to term the act of human trafficking. The terminology of the term trafficking is a new issue in Indonesia. Until now there is no exact translation into Indonesian and can clearly distinguish it from "trading" (trading). Even with the use of inappropriate synonyms, the term trafficking is used to translate the term trafficking (Rachmad Syafaat, tt: 11).

According to Law no. 21 of 2007 concerning the Eradication of the Crime of Trafficking in Persons Article 1 paragraph (1), trafficking in persons is the act of recruiting, transporting, harboring, sending, exchanging or getting a individual by implies of dangers of savagery, utilize of constrain, capturing, confinement, forgery, fraud, abuse of power or position of vulnerability, debt bondage or giving payments or benefits, so as to get the assent of the individual who has control over the other individual, whether carried out inside a nation or between nations, for the reason of misuse or causing people to be exploited.

There are three elements contained in human trafficking, namely (Teguh Prasetyo, 2014):

1. Components of activity, which incorporate: enlisting, transporting, exchanging, covering up or receiving.

2. Components of implies (strategies) to control casualties, which incorporate: dangers, utilize, impelling, different shapes of viciousness, capturing, extortion, extortion, mishandle of control or a position of helplessness or giving/receiving or profiting to get the assent of the individual in control over the victim.

3. The components of the objective, which incorporate: misuse, at slightest for prostitution or other shapes of sexual abuse, constrained work, servitude, subjugation, and organ harvesting. 
Of the three elements, what needs to be considered is the element of purpose, because even though child victims are not limited to the problem of using the facilities, the goal is the same, namely exploitation (Harkristuti Harkrisnowo, 2005).

Trafficking in persons must also meet the elements (Day, 2007), namely:

1. If the act as referred to above causes people to be exploited.

2. Everyone who imports people into the domain of the Republic of Indonesia with the deliberate of being misused within the domain of the Republic of Indonesia or being abused in another nation.

3. Everyone who brings Indonesian citizens exterior the region of the Republic of Indonesia with the purposeful of being abused exterior the region of the Republic of Indonesia.

4. Everyone who adopts a child by promising something or giving something with the intention of being exploited.

5. Anyone who sends a child into or out of the country in any way that results in the child being exploited from school, if the family experiences an economic crisis or a food crisis.

Trafficking may be a advanced frame of human subjugation (Nurhenny, 2010). Subjugation is the condition of a individual being beneath the possession of another. A practice similar to slavery is the act of placing someone in the power of another person so that that person is unable to refuse a job that was unlawfully ordered by the other person to him even though that person does not want it (Rika Saraswati, 2015).

Trafficking in persons is additionally one of the most exceedingly bad shapes of treatment and a violation of human dignity, which in itself is a violation of human rights (Nurhenny, 2010).

Trafficking is caused by a whole thing consisting of various conditions and different problems. Factors that influence this are among others due to the lack of awareness of many people who migrate to find work, both in Indonesia and abroad, do not know about the perils of trafficking and don't know the strategies utilized to betray or trap them in their work. mishandled or slavery-like work (Heri Santoso, 2012).

The most vulnerable groups to become victims of trafficking in persons are children. The main factor that causes human trafficking is poverty. According to Firdaus, the low economic level is often the source of the emergence of a number of social problems, including the increasing number of beggars and neglected children. Not infrequently poverty is the basis for the emergence of family disharmony, including the practice of trafficking in girls for the purpose of prostitution (Firdaus, 2004). The lack of information about human trafficking is also often used by perpetrators to attract their prey (Marjan Miharja, 2019)

In addition, the factor that causes this is because the age of the child is very easy to be deceived by adults, it is easy to give promises or lure from traffickers. In addition, the rampant trafficking of children is also caused by environmental factors and the development of hedonistic behavior and a consumptive lifestyle at the age of children. Children are easily influenced by friends in their association, so they are entangled in child trafficking.

Girls are much more likely to be victims of trafficking than boys or boys. Especially if we talk about trafficking in persons for prostitution and other forms of sexual exploitation, and also in the exploitation of domestic work which is more similar to the practice of slavery in the modern era. Trafficking in persons is a serious manifestation of the feminization of poverty and the greater challenges faced by women and girls in the world 
characterized by gender discrimination, both inside and outside the job market (Sulistyowati Irianto et al, 2007).

The mode of child trafficking usually begins with a manipulative stage. Perpetrators usually commit fraud against potential victims. The mode is as follows:

1. The perpetrator is acquainted with the child either directly or indirectly. Indirect introductions are usually done through social media.

2. Approach potential victims. The approach is usually done through a friend of the victim or a friend of the child's age. Children who are often approached are children who come from poor families, drop out of school, do not have special skills, children who come from disharmony families, children who lack love, children who are accustomed to the nightlife, or children who want to live in luxury. instantly. Especially for the sale of children, the perpetrators usually approach poor families or women who give birth to children without a husband.

3. Child trafficking is also carried out by kidnapping and holding children. The goal is that children are exploited or adopted as children for families who do not have children.

4. Perpetrators give promises to potential victims in the form of jobs with lucrative wages or benefits in the form of money and luxuries.

5. The form of work promised by the perpetrator is not accompanied by a valid agreement and does not provide information to potential victims about the risks they may experience.

6. The promised work and wages usually do not match reality and some victims do not get paid for their work. Some have to pay debts to those who employ them and even experience violence.

The perpetrator of the wrongdoing of trafficking in people initiates, transports, exchanges, harbors or gets people for the reason of catching, catching or abusing the individual within the hone of misuse in all its shapes with dangers of savagery, utilize of drive, seizing, fraud, extortion, mishandle of control or a position of defenselessness, or giving installments, or benefits so as to get the assent of the individual who has control over the casualty (Irsan, 2007).

Children as victims of trafficking are not only for the purpose of prostitution, but are also employed without the promised wages or even no wages at all. Some children are employed in nightclubs, enter into contract marriages, some are sold as adopted children and the child's parents get paid for it.

Children are a gift from the Almighty. Children are the nation's assets that must be guarded and protected.

Child security is all endeavors made to form conditions so that each child can carry out his rights and commitments for the advancement and development of children actually, physically, rationally and socially (Maidin Gultom, 2010).

Protection of children must be pursued in various ways, including taking preventive measures so that children do not become victims of trafficking in persons.

Some things that can be done to prevent child trafficking are:

1. Improving the family economy. Poor family life causes some children to take the initiative to work for the sake of survival. Sometimes this causes children to become victims of human trafficking. Therefore, parents should improve their economic life.

Although poverty is considered as the main factor causing child trafficking, poverty is not the only indicator for the occurrence of child trafficking. However, poverty will put people in a desperate position that makes them vulnerable to exploitation (Nurhayati. S., 2016). 
2. Creating a harmonious family. In a harmonious family, children can establish good communication and will bring happiness to children. if the child is happy, it is not easy to go along with the other party who gives false happiness. One of them is a child trafficker.

3. Increasing religious understanding, especially for parents, so that it is not easy to trade children. In many cases, it is parents who act as child traffickers.

4. Increase understanding to children and the community about the negative impacts of child trafficking. Trafficking in children has a negative impact that is very detrimental to the growth and development of children, and allows the future of children to be damaged.

5. Improve supervision of children. Supervision of children is not only carried out by parents and other families. Supervision must also be carried out by parties related to child protection, the government, the community, and the school. Supervision is carried out so that children are not easily trapped in human trafficking.

6. Increase public knowledge that child trafficking is a crime regulated by law and has legal consequences. Child trafficking is a crime or criminal act which, if committed, will have an impact on the perpetrator. The legal consequence is that each perpetrator will be subject to criminal sanctions in accordance with applicable regulations. By knowing this, it is hoped that (especially potential perpetrators) will be afraid to do so. According to Waluyo, this threat must be known to the general public and make everyone afraid of committing a crime and must be a deterrent effect (Waluyo. B., 2014).

7. Keep children away from hedonistic lifestyle and consumptive behavior. This is often experienced by children and is very detrimental of course. Children can be individualistic, prioritize their own interests, forget about other parties, have a high sense of prestige, always follow trends and want to live life in luxury. If it is not fulfilled from the parents, the child will easily fall into human trafficking. Parents play an active role in preventing children from such behavior. By always applying a simple lifestyle since children at an early age, trying on the right path, and always being grateful in every condition.

8. Get to know the child's social environment. It is necessary to know the parties who associate with children. Especially at this time, the social environment of children is not only found in the surrounding community and the world of education, but also in the association of social media.

9. Improving children's education. Children who have a good education will be able to distinguish good actions or words from bad ones. They will not be easily fooled by the hopes or the lure of other parties who promise beautiful things from child trafficking activities.

10. Improving the skills of school dropouts. Out of school children who do not have special skills are usually given promises to work by traffickers and are accompanied by large wages. To avoid this, children are given skills so that they can work according to their skills or even be able to open jobs for themselves.

\section{CONCLUSION}

Prevention is part of efforts to protect children's future and is useful in preventing children from being trapped or tricked by child traffickers, so that children are not easily fooled by job vacancies and promised wages. Prevention is also carried out to minimize child trafficking. 


\section{REFERENCES}

Day. A.J. (2007). Tindak Pidana Perdagangan Orang, Seminar tentang Sosialisasi UU Pemberantasan Tindak Pidana Orang, Bandung.

Firdaus. (2004). Respons LSM terhadap Perdagangan Anak Perempuan, Kerjasama Ford Foundation dengan Pusat Studi Kependudukan dan Kebijakan Universitas Gadjah Mada, Yogyakarta.

Heri Santoso. (2012). Penegakan Hukum \& Pencegahan Trafficking di Indonesia, Media Perkasa, Yogyakarta.

Harkrisnowo. H. (2003). Laporan Perdagangan Manusia di Indonesia. Sentra HAM, UI, Jakarta. Dalam Penghapusan Perdagangan Orang (Trafficking in Persons) di Indonesia, Tahun 2004-2005, Kementerian Koordinator Bidang Kesejahteraan Rakyat, Jakarta.

Irsan, K. (2007). Hak Asasi Manusia Suatu Pengantar, Sinar Grafika, Jakarta.

Nurhenny, H. (2010). Tindak Pidana Perdagangan Orang Kebijakan Hukum Pidana dan Pencegahannya, Sinar Grafika, Jakarta.

Sulistyowati Irianto dkk. (2007). Perdagangan Perempuan Dalam Jaringan Pengedaran Narkotika, Yayasan Obor Indonesia, Jakarta.

Maidin Gultom. (2010). Perlindungan Hukum terhadap Anak dalam Sistem Peradilan Anak di Indonesia, Refika Utama, Bandung.

Waluyo,Bambang. (2014). Pidana dan Pemidanaan, Sinar Grafika, Jakarta.

Mahrus Ali dan Bayu Aji Pramono. (2011). Perdagangan Orang, Dimensi, Instrumen dan Pengaturannya di Indonesia, Citra Aditya Bakti, Bandung.

Marjan Miharja. (2019). Efektifitas Penanggulangan Perdagangan Orang (Human Trafficking) di Indonesia, Qiara Media, Jakarta.

MG. Endang Sumiarni dan Chandera Halim. (2000). Perlindungan Hukum Terhadap Anak Dalam Hukum Keluarga Cet. I, Universitas Atma Jaya Yogyakarta, Yogyakarta.

Nashriana. (2012). Perlindungan Hukum Pidana Bagi Anak di Indonesia, Rajawali Pers, Jakarta.

Nurhayati, S. (2016). Aspek Hukum Perlindungan Saksi dan Korban Perdagangan Anak (Human Trafficking). YUDISIA: Jurnal Pemikiran Hukum dan Hukum Islam, 6(1), 7196.

Rachmad Syafaat, tt, Dagang Manusia Kajian Trafficking terhadap Perempuan dan Anak di Jawa Timur, Lappera Pustaka Utama, Yogyakarta.

Rika Saraswati. (2015). hukum Perlindungan Anak di Indonesia, citra Aditya bakti, Bandung.

Teguh Prasetyo. (2014). Hukum Pidana, Rajawali Pers, Jakarta. 